\title{
Inhibited privatization: a hurdle race over vested interests
}

\author{
Marcin Senderski, Kozminski University
}

\begin{abstract}
This paper recognizes vested interests as one of the primary premises that reduce the effectiveness of privatization policy, stall its momentum and produce structural problems in the long-run. Both exogenous and endogenous drawbacks are cited, but the main focus is put on the dynamism of vested interests' character, interconnectedness and evolution. Policy makers have been long aware of the existence of activities rooted in vested interests including empire building behaviors, creation of sinecures or extravagant management style. Hence, the fundamental effort here is put on the identification of emerging vested interests that were typically not considered by scholars. The channels through which conventional vested interests have snowballed over time are emphasized. This includes casting a closer glance at family employment, as well as at sports sponsorship arrangements, which emerge as the favorite domain of marketing activity for Polish state-owned enterprises. The research of available literature is performed, along with its application to the Polish case, and insightful observations concerning the anatomy of privatization-related reluctance. Rough policy recommendations conclude the paper.
\end{abstract}

\section{Keywords}

Privatization; Poland; vested interests; state-owned enterprises.

\section{JEL classification}

L33; D72; D73. 


\section{Introduction}

The principal goal of the paper is to perform an in-depth investigation into the character of privatization-related vested interests that hamper the pace and depth of ownership transformation. The case of Poland is used as an example, both because of its familiarity to the author, and the presence of phenomena that are tackled in this paper, the pervasiveness of which may have been observed throughout recent years. Vested interests were of course perceptible throughout consecutive stages of privatization in Poland from its very beginning, but the evidence here is designed rather to illustrate the contemporary struggle to overcome the residual resistance. The term "vested interests" embodies various political interests expressed by individuals or groups, deriving rents from a given state-owned entity and capable of forming pressure aimed at the preservation of status quo, which is favorable for them, but which puts taxpayers at a disadvantage. Another interesting frame for the notion of vested interests has been presented in Krusell and Rios-Rull (1996) who studied political obstacles to technological innovations. They depict this phenomenon by the incumbents blocking the emergence of novelties by influencing the regulatory process.

There are undoubtedly some merits behind the government's presence in the corporate world and the intention of this article is neither to analyze its legitimacy, accuracy and effectiveness, nor to argue in favor of privatization's inherent value. In fact, as Hertog (2010) proved for the Persian Gulf monarchies, it would be too bold to make an identity relationship between public ownership and ineffectiveness. It is equally troublesome to infer high-level consequences of too much state in the economy, given the plethora of intermediate variables, differences in initial conditions and adopted development models. It is also ambiguous what consequences political connectedness has for companies involved in political campaigns (See Newton and Uysal, 2013).

Hence, instead of seeking strict evidence for the ineffectiveness of state-owned enterprises (later referred to as SOEs), this paper rather relies on a generic, primitive assumption that private property in the broad economy is more effective than public property. The paper is solely to stress that there is a number of supplementary motivations that derail SOEs from their shareholder value-oriented regime and make policy makers not cut the umbilical cord that feeds them with generous governmental perks. At the same time, being aware of the consequences of flawed state ownership is important as it attests to the importance of this article. First, vested interests and rent seeking behaviors can distort the economic efficiency of policy design and implementation in the domain of management of economic resources (Jamasb, 2006:24). Second, they might have prolonged consequences for the level of development of the private sector and financial markets (Roland, 2001). Third, protracted privatization may have insidious influence on public finance, leading to its sub-optimal structure and putting off necessary reforms. A certain sort of extra income dependency can be observed, meaning that the government takes yearly privatization revenue for granted, treating it as filling material for budget deficit (see e.g. limi, 2003). Henceforth, gradual and sluggish privatization postpones the need to introduce substantial, but openly disliked policy shifts. With swift privatization, government would be injected with a one-off cash boost, but in the coming years more courageous policies would have to be implemented.

Rosa and Pérard (2010) stress that privatization-related literature is concentrated around two central subject matters: optimal privatization methods and efficiency gap between SOEs and private companies. Particularly, the ideological component that drives decision makers is unexploited. Although there is a broad literature also on the motivation of political actors to privatize or externalities associated with privatization, there is still a considerable deficit in comprehending the inhibitors to ownership transformation. Naturally, the political dimension is recognized and the political theory of privatization is developed in such papers as Boycko, Shleifer and 
Vishny (1996), Opper (2004) or Bortolotti and Pinotti (2008), but the existing literature more often than not adopts a static stance towards interest groups, usually ignoring the fact their interests do evolve over time.

On a statistical note, the history of privatization in Poland dates back to 1981 (the introduction of market socialism policy), but it is not before the collapse of communist regime in 1989 and pushing through a series of privatization bills until the property transformation gathered its momentum (for more extended recapitulation refer e.g. to Kowalik, 1991). Between 1990 and 2008, nearly 7,500 (85.4 percent as of 1990) state enterprises have been put under some form of privatization. However, this figure is remarkably deceiving, as more than every fifth enterprise was just 'commercialized' into 'sole-shareholder company of the State Treasury', which is quite immaterial alteration as compared with the status of SOE. Moreover, about 1,000 firms from the (statistical) privatization pool were dissolved, while even more than that were handed over to a government-dependent entity, the Agricultural Property Agency (See Central Statistical Office in Poland, 2009).

Naturally, privatization in Poland is by far not a textbook example of perfectly failed policy. Tache (2008:12-14) enumerates such patterns, providing an example of her own country, Romania, as well as Russia, Bulgaria and Serbia, branding this model as a "patrimonial capitalism". An extreme politicization of the underlying privatization schemes led virtually to a disappearance of hidden intrigues and charades, with vested interests being overtly displayed instead. For instance, members of the Romanian Parliament, sheltered by immunity, did not hesitate to perform managerial functions in the SOEs. In Poland, misconduct of such gravity has not been seen. To provide a complete picture, however, it is important to add that vested interests related to privatization do not necessarily ruin the whole market-oriented effort. For instance, as Rondinelli and Yurkiewicz (1996:145) write, 'the development of small and medium-sized enterprises and the spread of entrepreneurial activity were far more important than privatization of state enterprises in moving Poland toward a market system'. Nevertheless, in some jurisdictions, such as Russia, the spoils system determined the quality of transition, and paralyzed market-oriented reforms (Moors, 1997; Fischer and Sahay, 2000:21), as 'the state was easily captured by well-organized industrial interests' (Kapstein and Milanovic, 2000:29).

The paper is structured as follows. This introduction, containing the very brief outlook of privatization-related struggles in Poland, is followed by the discursive chapters on exogenous and endogenous sources of vested interests. The borderline between them happens to be blurred, but in general the exogenous originate outside the domain of policy makers, while the endogenous are rooted in politics. Afterwards, the dichotomy between conventional and emerging vested interests is presented, the latter being the phenomena that arose relatively recently and have not been so far extensively covered by scientific research. What comes next is the illustration of the emerging vested interests on the basis of a concise case study carried out with regard to the largest Polish SOEs. Policy recommendations and further research proposals are derived in the final chapter.

The paper's contribution to the literature comes in two forms. First, it firmly introduces vested interests as a dynamic phenomenon, whereas the past literature was at best agnostic about their nature, or portrayed them as a static occurrence. Second, the supportive value of this paper is that it offers a taxonomy of vested interests, not only dividing them into conventional vs. emerging, but also into exogenous vs. endogenous. The dynamics between these interconnected groups is also presented throughout the article.The conclusions may both enrich policy makers' comprehension of vested interests domain, and assist in counteracting the overly improper use of political clout.

As a rough introduction to the insights into exogenous and endogenous sources of privatization reluctance, one may review the following chart that should facilitate to keep up with the reasoning presented in this article. 
Figure 1. Exogenous and endogenous sources of privatization reluctance

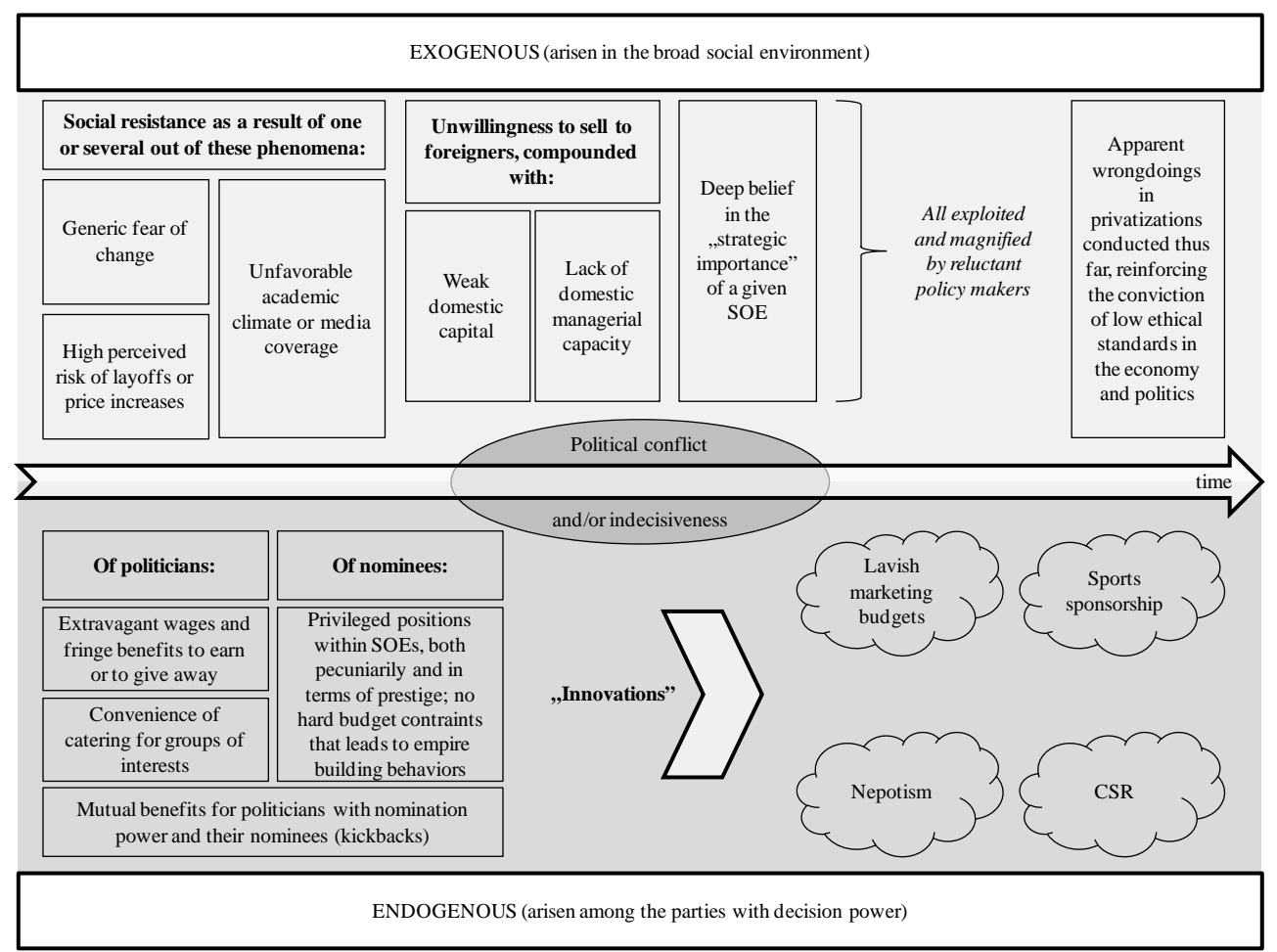

Source: own taxonomy

\section{Exogenous determinants of sluggish privatization}

Although the intention of this paper is more to explore the endogenous dimension of privatization-related negligence, the brief recapitulation of exogenous factors is also desirable. As Bel and Fageda (2008:6) write, 'it is commonly assumed that public employees and unions are in favor of internal production, while industrial interests have a greater preference for privatization'. The privatization effort is indeed quite often impeded by the trade unions empowered by directly 'touched' employees (Warner and Hebdon, 2001; Careja and Emmenegger, 2009). Privatization issues are thus still central to positioning strategies espoused by political parties in transition states. In aggregate, one should agree with Bortolotti and Faccio (2004:2) remarking that there are few stories that document governments privatizing enthusiastically, and'most of the news stories depict governments that are faced with stiff opposition from many vested interests, but are forced to privatize because of budgetary shortfalls'. Hence, exogenous determinants of sluggish privatization are, at least by some scholars, seen as dominant and powerful. The table on the next page shows the selected data for state-owned entities in OECD economies in 2009.

Based on the inputs presented in this table, the naïve correlations are as follows (figures in brackets indicate the correlation coefficient after excluding Norway, which is outstandingly peculiar with its sovereign wealth funds):

- Employees as percent of population vs. GDP per capita: $0.043(-0.342)$

- Market value as percent of GDP vs. GDP per capita: $0.372(0.023)$

- Employees as percent of population vs. Corruption Perception Index: -0.053 (0.193)

- Market value as percent of GDP vs. Corruption Perception Index: $0.180(0.072)$

- Employees as percent of population vs. Index of Economic Freedom: -0.383 (0.431)

- Market value as percent of GDP vs. Index of Economic Freedom: -0.167 (-0.201) 
The caveats are particularly that correlation coefficients say nothing about causality and that it is a narrow and static approach, as the readily available data do not allow for full panel analysis. In fact, in order to advance to a more comprehensive picture, instead of having considered listed and non-listed enterprises, one should also include the statutory corporations, i.e. the units created by statutes. Although Christiansen (2011) has in fact done it, the OECD data set he uses has many nonnegligible blanks.

Referring to the academic discussion, not everyone had incentives to make key industries free from the shackles of communist continuum back in the early 1990s. Some, "shock therapists", worried that if the privatization did not proceed quickly, the overwhelming pool of vested interests would stimulate a reversion to socialism. Others, 'gradualists' were uneasy about hurried reforms, claiming 'they would be a disaster - economic failures compounded by political corruption - opening up the way to a backlash' (Stiglitz, 2002:27). The main arguments of the big bang enthusiasts centered around two focal points: detaining asset stripping and precluding vested interest groups from blocking privatization later on (Fischer and Sahay, 2000:12). Indeed, radical actions seem to be superior to gradual actions when it comes to tackling vested interests, since the latter allow 'defenders of the status quo far greater latitude to sabotage reform' (Megginson and Netter, 1998:29). The burden of vested interests tied to the ancien regime was also recognized by Earle and Gehlbach (2002:5) who suggested a 'strong state' as a firewall against this threat. Whereas in the 1990s "shock therapists" received vast support provided by an empirical literature, they were finally challenged by "gradualists", who have revisited the models and pointed out their substantial and methodological flaws. Overlooking initial conditions and institutional frameworks, and confusing the speed and the depth of reforms were the focus of critique (Campos and Coricelli, 2002:51; Godoy and Stirlitz, 2006:20). Even Sachs himself admitted afterwards that privatization policy prescriptions should contain less ideology, and be rather tailored to the country's characteristics, since while ownership certainly matters, institutional infrastructure matters just as much (Estrin et al., 2007:37; Wallsten, 2002; Zinnes, Eilat and Sachs, 2001:166).

The break through periods are inseparably associated with extraordinary policies, initiated immediately as the country embarked on transition. First, 'the magic of the moment' facilitated winning, at low or no cost, public consent for reforms. Second, it made it easier to dismantle disorganized vested interests (Earle and Gehlbach, 2002:6). However, much time has passed since Eastern European societies last had an occasion to take advantage of this approach, because the period of extraordinary policies has left for good. While at the very beginning of the transition road, the reformative enthusiasm and people's approval of undergoing economic changes indeed provided an auspicious environment, it deteriorated quickly after the wrong doings of privatization have been gradually made apparent. Members of nomenklatura, supposedly most proficient when it came to understanding a complicated legal framework, have engaged in 'spontaneous privatization' right after new economic policies came into effect, and managed to strip 'some assets of their firms through transfer pricing, sweet deals with foreigners, and other plundering devices' (Tirole, 1991:222). Pittance savings of the ordinary population precluded it to take its slice of the new shareholding structures. As spotted by Stiglitz (2002:143), even if some would be eager to make use of their nest egg to take over an enterprise, they would probably not be able to restructure it, given galloping inflation and risk averse or infant financing providers. As domestic investment capabilities were scarce at the beginning of the 1990s, the immense amounts of state-owned capital failed to attract broad masses. 
Table 1. Statistics of selected OECD member countries in 2009.

\begin{tabular}{|c|c|c|c|c|c|c|c|c|c|c|c|c|c|c|}
\hline \multirow[b]{3}{*}{ Country } & \multirow{3}{*}{$\begin{array}{l}\text { GDP p.c. } \\
(P P P) \\
O O O \cup S D\end{array}$} & \multirow{2}{*}{\multicolumn{2}{|c|}{ Rankings }} & \multicolumn{9}{|c|}{ Enterprises majority-owned by the central level of government } & \multirow{2}{*}{\multicolumn{2}{|c|}{$\begin{array}{l}\text { Relative measures indicating the } \\
\text { size of state-owned units }\end{array}$}} \\
\hline & & & & & Listed & & & Non-listed & & & Total & & & \\
\hline & & $\mathrm{CPI}$ & IOEF & Units & Employees & $\begin{array}{l}\text { Market } \\
\text { value }\end{array}$ & Units & Employees & $\begin{array}{l}\text { Market } \\
\text { value }\end{array}$ & Units & Employees & $\begin{array}{l}\text { Market } \\
\text { value }\end{array}$ & $\begin{array}{l}\text { Employees as } \\
\% \text { of population }\end{array}$ & $\begin{array}{c}\text { Market value as } \\
\% \text { of GDP }\end{array}$ \\
\hline AUS & 41.43 & 8.7 & 82.6 & 0 & 0 & 0.0 & 7 & 8283 & 4.2 & 7 & 8283 & 4.2 & 0.04 & 0.47 \\
\hline AUT & 39.26 & 7.9 & 71.2 & 2 & 28741 & 8.2 & 6 & 50459 & 7.8 & 8 & 79200 & 16.0 & 0.95 & 4.87 \\
\hline BEL & 36.90 & 7.1 & 72.1 & 1 & 17371 & 13.2 & 7 & 74990 & 44.6 & 8 & 92361 & 57.8 & 0.86 & 14.51 \\
\hline CAN & 38.63 & 8.7 & 80.5 & 0 & 0 & 0.0 & 33 & 105296 & 21.6 & 33 & 105296 & 21.6 & 0.31 & 1.66 \\
\hline $\mathrm{CHL}$ & 15.92 & 6.7 & 78.3 & 1 & 156 & 0.2 & 9 & 5559 & 2.7 & 10 & 5715 & 2.9 & 0.03 & 1.08 \\
\hline CZE & 25.88 & 4.9 & 69.4 & 1 & 33000 & 25.3 & 82 & 38200 & 9.9 & 83 & 71200 & 35.2 & 0.68 & 12.97 \\
\hline DNK & 38.63 & 9.3 & 79.6 & 0 & 0 & 0.0 & 11 & 8680 & 8.3 & 11 & 8680 & 8.3 & 0.16 & 3.89 \\
\hline EST & 19.98 & 6.6 & 76.4 & 0 & 0 & 0.0 & 32 & 16261 & 2.9 & 32 & 16261 & 2.9 & 1.21 & 10.85 \\
\hline FIN & 35.87 & 8.9 & 74.5 & 3 & 24844 & 29.4 & 28 & 61187 & 16.3 & 31 & 86031 & 45.7 & 1.61 & 23.86 \\
\hline FRA & 35.11 & 6.9 & 63.3 & 2 & 176347 & 116.1 & 30 & 120386 & 41.6 & 32 & 296733 & 157.7 & 0.47 & 7.17 \\
\hline DEU & 35.96 & 8.0 & 70.5 & 0 & 0 & 0.0 & 57 & 66419 & 22.9 & 57 & 66419 & 22.9 & 0.08 & 0.78 \\
\hline HUN & 20.44 & 5.1 & 66.8 & 0 & 0 & 0.0 & 346 & 150528 & 6.7 & 346 & 150528 & 6.7 & 1.50 & 3.27 \\
\hline ISR & 27.71 & 6.1 & 67.6 & 0 & 0 & 0.0 & 29 & 50264 & 43.2 & 29 & 50264 & 43.2 & 0.67 & 20.83 \\
\hline ITA & 32.36 & 4.3 & 61.4 & 0 & 0 & 0.0 & 25 & 289329 & 105.4 & 25 & 289329 & 105.4 & 0.48 & 5.38 \\
\hline KOR & 26.22 & 5.5 & 68.1 & 8 & 39599 & 38.3 & 48 & 81056 & 139.4 & 56 & 120655 & 177.7 & 0.24 & 13.72 \\
\hline MEX & 14.19 & 3.3 & 65.8 & 0 & 0 & 0.0 & 45 & $\mathrm{n} / \mathrm{a}$ & 2.2 & 45 & $\mathrm{n} / \mathrm{a}$ & 2.2 & $\mathrm{n} / \mathrm{a}$ & 0.14 \\
\hline NLD & 41.16 & 8.9 & 77.0 & 0 & 0 & 0.0 & 28 & 60355 & 74.1 & 28 & 60355 & 74.1 & 0.36 & 10.84 \\
\hline NZL & 29.87 & 9.4 & 82.0 & 1 & 10726 & 0.5 & 17 & 17107 & 9.1 & 18 & 27833 & 9.6 & 0.64 & 7.36 \\
\hline NOR & 54.61 & 8.6 & 70.2 & 3 & 74723 & 104.7 & 33 & 50479 & 18.3 & 36 & 125202 & 123.0 & 2.56 & 46.06 \\
\hline $\mathrm{POL}$ & 18.79 & 5.0 & 60.3 & 13 & 184079 & 59.5 & 573 & 542082 & 34.0 & 586 & 726161 & 93.5 & 1.89 & 12.92 \\
\hline PRT & 25.27 & 5.8 & 64.9 & 0 & 0 & 0.0 & 42 & 81465 & 16.6 & 42 & 81465 & 16.6 & 0.77 & 6.21 \\
\hline SVN & 26.93 & 6.6 & 62.9 & 3 & 3048 & 0.9 & 33 & 22276 & 3.1 & 36 & 25324 & 4.0 & 1.24 & 7.25 \\
\hline ESP & 32.15 & 6.1 & 70.1 & 0 & 0 & 0.0 & 115 & 106963 & 36.3 & 115 & 106963 & 36.3 & 0.23 & 2.45 \\
\hline SWE & 37.29 & 9.2 & 70.5 & 0 & 0 & 0.0 & 43 & 143253 & 66.1 & 43 & 143253 & 66.1 & 1.53 & 18.90 \\
\hline $\mathrm{CHE}$ & 46.81 & 9.0 & 79.4 & 1 & 19813 & 19.8 & 1 & 7534 & 0.7 & 2 & 27347 & 20.5 & 0.35 & 5.59 \\
\hline GBR & 35.36 & 7.7 & 79.0 & 1 & 160900 & 50.7 & 12 & 202668 & 5.5 & 13 & 363568 & 56.2 & 0.59 & 2.59 \\
\hline
\end{tabular}

Foundation \& Wall Street Journal, www.heritage.org; OECD, www.stats.oecd.org. CPI stands for the Corruption Perception Index, while IoEF stands for the Index of Economic Freedom. 
Clearly, following the years of communist propaganda according to which the state's property belonged to people, it was problematic to make people satisfied as many of them felt empty-handed. Such an inference may be justified on the basis of Pentor's survey about privatization sentiments (see chart below). Nevertheless, the research has been ceased after 2004, yet before most recent and highly profitable initial public offerings (IPOs) of SOEs have been concluded (Megginson and Bortolotti, 2011), and further estimates are not available. Now it seems that a certain reluctance prevails if the vested interests of citizens are endangered rather than those of politicians. Therefore, ownership transformation is hampered in health care and utilities. Nevertheless, it is beyond discussion that privatization is a two-edged sword for the state authorities, and some modes of ownership transformation (e.g. Czechoslovakia's voucher scheme, or - more up-to-date - Poland's IPOs) may prove helpful in building up political capital and thus in increasing government's popularity. Privatization of SOEs through the mass enfranchisement of employees may also contribute to mitigating the anti-privatization movement within the company (Shafik, 1996), but its track record in Central and Eastern Europe is not very impressive, presumably due to mentality issues (Castater, 2002:14-20; Kozarzewski, 2008:257-260). Moreover, the choice of a scheme is tricky as well. Whereas Czechoslovak privatization was in fact a 'give-away to outsiders' (glorious but inefficient), the Russian case was rather a 'give-away to insiders' (definitely inglorious) according to Roland's (2000) typology. The search for a golden mean continues.

Figure 2. A survey regularly carried out by Pentor until 2004, in which the question asked is: 'Do you generally support the efforts aimed at privatization of the Polish economy?'

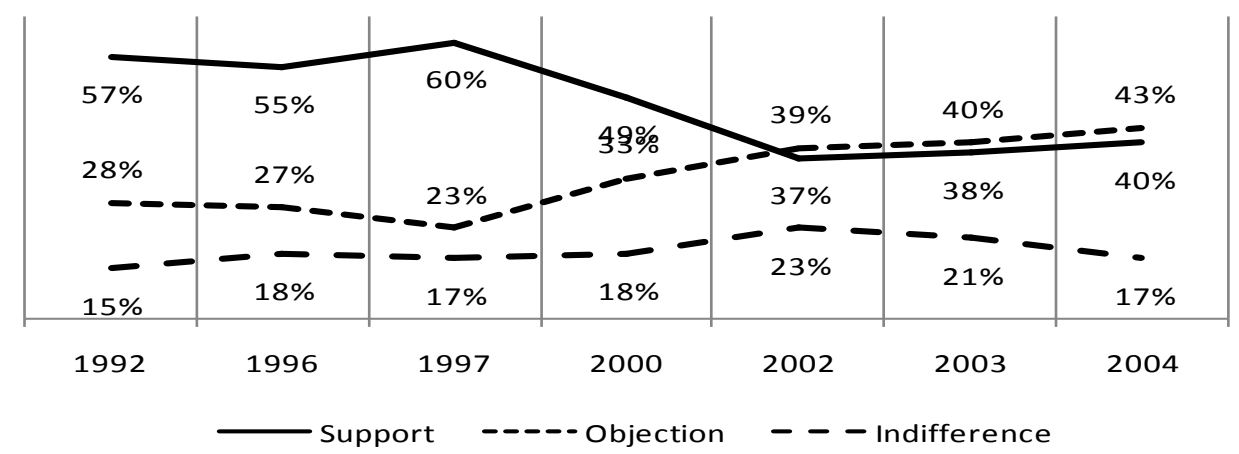

Source: Ministry of Treasury (2005:279).

The exogenous sources of policy makers' reluctance towards privatization are also fueled by the prevalent term 'thievish privatization', implying that ethical standards lag behind the pace of structural transformation. This finding was confirmed by Denisova, Eller, Frye and Zhuravskaya (2010:4) who claim that 'political elites have used public sentiment of illegitimacy of privatization to redistribute assets to themselves or their supporters'. A similar survey has been conducted for Latin America by Checchi, Florio and Carrera (2005), who found out that privatization discontents are predominantly poor, live in countries with high income inequalities, whereas privatizations in question were large, quick and involved such public utilities as water or electricity. Yusuf (2009:73) enumerates a number of "sins" of privatization in transition economies, and to name just a few: sales to insiders, asset stripping, weak managerial capabilities, limited competition, feeble regulation, all amplified by resistance from vested interests. Godoy and Stirlitz (2006:22) hypothesize that the countries that embarked on rapid privatizations may suffer from the prolonged problem that property rights lack legitimacy in society. The societal approval of the pace of economic reforms was underscored by Watts, Walstad and Skiba (2002). 
State authorities, in fact, tend more to explore the public concerns than to undertake education campaigns to minimize them. They usually take public unrest at its face value and reinforce it, by emphasizing the argument of allegedly strategic importance of particular enterprises or branches, which seems to be a plausible excuse. The strategic importance is to some extent reflected in the Polish corporate law. Radwan and Regucki (2012:17-18) present the articles of association of PGNiG (a SOE dealing with exploration and production of natural gas and crude oil) affirming that 'the State may consent to the company taking actions or making investments that permanently or temporarily reduce the company's economic efficiency, but are necessary for maintaining the energy security of the country'. This passage instructs that the state intervention is rationalized, as it is capable of endorsing social benefit at the cost of economic benefit of the corporation. The tensions between the commercial and non-commercial nature of SOEs are more thoroughly explored by Christiansen (2013). In contrast, Raszewski (2012:130-131) warns that labeling something as a security issue (i.e. a strategically important matter) allows for dealing with such a problem 'behind closed doors'. In fact, such a securitization becomes an extreme form of politicization.

However, strategic status may be ascribed only to a fraction of SOEs (e.g. energy industry, petroleum industry, rail transport, aviation, shipbuilding, arms industry, coal mining industry), whereas still hundreds of enterprises remain de facto isolated from stimulating free market mechanisms. This "excuse" is amplified by another. Many people are hesitant towards potential buyers, mainly foreign companies, which do not take into account Polish national interests. However, the argument of national interests is incomplete, as markets deemed strategic are usually strictly supervised by domestic regulatory bodies that restrain potentially abusive behaviors of foreign agents. Moreover, the dual role of state being both the owner and the regulator may give birth to conflicts of interest (Bauer, 2003). Also, the question of whether public authority makes shareholders better off, as compared with private management, remains highly controversial. An overpaid (2,34 bn USD for the control stake) deal of PKN Orlenpurchasing Lithuanian Mažeikiairefinery (MažeikiųNafta) in 2006 would have probably never taken place if PKN Orlen had not been controlled by the State Treasury. The transaction was carried through due to political reasons, which were later confirmed by both Orlen's executives and political leaders, but the refinery's operations are significantly hampered by the anti-Polish activity of Russian oligarchs (Vitkus, 2009:31-33).

On the borderline between exogenous and endogenous vested interests lies the ideological fragmentation of the political scene, i.e. the internal conflict of political elites, though existing as a consequence of inconclusive results of democratic elections. As Bortolotti and Pinotti (2008:18) argue, greater political fragmentation (precisely: the number of agents with veto power) is the factor entailing longer delays to implement large scale divestiture. The same is confirmed for economies considered developed, like Italy, where economic benefits from privatization have not been realized in full partly because of the 'inherent weakness of the coalition governments that have run the country' (Goldstein and Nicoletti, 2003:30). Needless to add, an unstable political setting is highly likely to arise in transition states (Lipton and Sachs, 1990:298-299; Stark, 1990; Šikulová and Frank, 2013:30). Consequently, at the very beginning of the transition route, foreign investors are usually concerned about huge political risks. They not only risk low returns, but also, if unlucky, may have their assets seized by the next government, after being accused of, say, illegitimate privatization (Stiglitz, 2002:144). Nevertheless, as Rattsø (2012) evidenced for Norway, political conflict there also raises the influence of interest groups around SOEs. The example of an abundant state struggling with the same shortcoming as transition economies adds up to the universality of this finding. On a related note, Imai (2009), who examined the privatization of Japan's postal saving system, found robust evidence for incredibly complex legislative behavior with plethora of political factors involved and with conflicts not only between, but also within political parties. 
After more than 20 years of successful market economy in Poland, the existence of state-owned banks, power plants, refineries and coal mines, in addition to still considerable amount of minority stakes, is difficult to apprehend. Since at the beginning of transition political agents may truly worry about layoffs and broadly understood social cost, these factors should diminish as time goes on (Agarwal and Nunnenkamp, 1992:18; Godoy and Stirlitz, 2006:18; Gupta, Ham and Svejnar, 2008:188-189). Overall, exogenous sources of vested interests typically lie behind the relatively idealistic interpretation of government inactivity in terms of ownership transformation of SOEs. As Megginson and Netter (1998:7) put it, benevolent governments, in this optimistic view, act 'in the (perceived) best interest of their citizenry' and are reluctant to resign from control fearing that the private sector would fail in providing necessary (strategically important) goods at an acceptable cost. Using less lofty language, the government simply takes exogenous vested interests for granted. The next chapter shows that the driving force of government's procrastination may equally well lie elsewhere.

\section{Endogenous sources of privatization aversion}

Despite the unambiguously important influence of civic dissatisfaction, resistance or anxiety towards privatization, a deal of effort in this paper is aimed at exploring the supply-side of privatization-related negligence. As we already know what societal convictions feed political agents and underpin their privatization aversion, let's now investigate the endogenous factors that flourish solely within the political environment. This is along the lines of Olofsgård (2003:11) who insists that 'vested interest groups do not necessarily come from outside', but the resistance to reform may be produced within the political elite. Anti-privatization vested interests' sources are twofold.

The first cradle constitutes nomenklatura being somehow in charge of a given enterprise's operations. They would oppose privatization as long as it takes in order to retain their own positions. Van de Walle (1989), who has not seen by then the post-communist privatization programs 'in all their glory', stated optimistically that political opposition to privatization is usually limited to the state bureaucracy. Although he also warned that this opposition may extend from corporate level to the level of the ministry overseeing this corporation, he rather failed to predict that these were politicians and not the bureaucracy that took the lead in impeding privatization as time went on

Hence, the second source is even more sustainable and also more sophisticated. Implicit knowledge instructs that having an umbrella over public enterprises is a valuable fringe benefit for politicians capable of taking advantage of it. Either directly or indirectly, supervisory boards of such entities are nominated by the ones currently in power. This creates boundless opportunities of appointing one's close associates and allies, possibly incompetent or not caring about the business. Decent wage, prestige and almost sure windfall severance package in case the political landscape changes, and the purge led by new government reshuffles the lineup of supervisory or management board members. Assumingit is not very unlikely that the enterprise's corporate governance may be rotten to the core, identical mechanism is due to be replicated downwards throughout the organizational chart, magnifying the impact of a political steering wheel.

This renowned mechanism, coined as a "spoils system" (alternatively, "patronage system"), originated in the United States and reached its climax during Andrew Jackson's presidency (1829-1837). However, it has been eradicated until nowadays, neither in Poland (see e.g. Majcherkiewicz and Gadowska, 2005; Nowakowski, 2005; Gwiazda, 2008) nor in its cradle, the United States (see e.g. Lewis, 2009). Promises of positions in return for political support, e.g. during an electoral campaign, are not the only way to abuse one's mandate. Politicians have in fact a broad portfolio of opportunities to endorse their proponents and temptations are all 
around, multiplied by prospective kickbacks in the form of pure cash or campaign contributions. Moreover, Dinç and Gupta (2011) found country-specific evidencethat no firm located in the state from which the Indian minister comes from (one who has jurisdiction over that firm), was ever privatized. As a matter of fact, India's overly bureaucratic and discretionary system was enough to create vested interests that prevented reform in the past decades (Singh, 2010:5). This result suggests that political patronage has a significant impact on the privatization decision. These mechanisms may be attenuated if politicians are restricted by the fear of private media coverage (Schoenman, 2005:50-51), but it materializes only provided that the abuse is evident and truly scandalous. The recent press coverage for Lubin, a headquarters of the state-owned giant KGHM, indicates that many local politicians sat in supervisory boards of KGHM or communal firms, although the remuneration taken from these firms has to be disclosed to the public, according to the domestic law (see Open Society Institute, 2002:418-419, for earlier instances of such misconducts).

Politicians' vested interests in Poland have been catalyzed for a long time via the "chimney bill" (limiting compensation for management in SOEs to six times the national average wage) that heavily curtailed top managers' willingness to work for SOEs. According to DLA Piper, a global law firm, the bill of this kind was unprecedented in the European Union (money.pl, 2008). Therefore, it is not surprising that comparative literature in this matter is non-existent. The bill was essentially a deterrent for top-notch specialists, and an open invitation to appoint less endowed executives. When the shortlist of contenders is unimpressive, it is relatively easy to pick pre-agreed candidates. As noted by Bohdan Wyżnikiewicz from the Gdansk Institute for Market Economics, the pathway to state-controlled management boards was open for young and inexperienced rookies, 'almostpensioners' or those attracted by political careers (RynekInfrastruktury.pl, 2012). The same finding, though indirect and deprived of detailed description, was revealed even by the Ministry of Treasury in Poland (2005:124) in its annual report on privatization. The "chimney bill" was alleviated in 2010 by Donald Tusk's government, privatizing quite eagerly as compared with preceding cabinets, though still exhibiting symptoms of excess procrastination. According to media reports, the "chimney bill" is now virtually "dead", with top SOEs, such as PolskaGrupaEnergetyczna (PGE), Enea, Tauron, Polish State Railways (PKP), JastrzębskaSpółkaWęglowa (JSW) or KompaniaWęglowa, bypassing the bill by making use of "managerial contracts".

A separate issue in the context of SOEs is the rotation of CEOs, implying the lack of long-term strategic stability.For instance, the current CEO of LOT Polish Airlines is the eighth since 2005 (not counting the interim ones). Similarly, PaństwowyZakładUbezpieczeń (PZU) had six CEOs between 2001 and 2007, and KGHM PolskaMiedź (KGHM) had seven CEOs between 2001 and 2009. Whereas in a free market company, the management is preoccupied with profit maximization tasks, the management of a state-controlled entity, regardless of their will, is tied by motivations of political rather than economic nature. The managers of statecontrolled enterprise are expected to maintain advantageous relationships with their benefactors, as numerous studies have validated the importance of managerial political connections (Faccio, 2010; Hillman, 2005; Khwaja and Mian, 2005; Wu and Cheng, 2011).

Bortolotti and Pinotti (2003:9) remind that it has already been largely documented that SOEs are a source of political rent for elected politicians, 'who can interfere in the operating activity of the company in order to cater specific interest groups'. Later on, they urge about most common modi operandi. These may include e.g. keeping redundant workers to push away the threat of unemployment and earn voters' admiration. This is what Rosa and Pérard (2010:112) would nickname as 'interestgroup real politik', while Boycko, Shleifer and Vishny (1996:310) argue that the spending politician may still be willing to subsidize a firm even after it is privatized, 
with the intent to 'buy' excess labor spending. All of this despite the fact that employment rose and the working class was better off after privatization (Galal et al., 1994; Megginson, Nash and van Randenborgh, 1994), contrary to anecdotal evidence.

Bjørnskov and Potrafke (2011:206) remark that vested interests more typically pertain to left-wing governments. By the same token, Li and Lui (2004:212-213) argue that right-wing governments may have greater motivation in privatization or liquidation of SOEs, as this would weaken trade unions, their natural foe. In the light of the above mentioned arguments, Schindele's (2003:13) view, underlining a substantial role of politicians' interest in the privatization process, seems to be an accurate synopsis: 'being able to use the basic trade-off between the costs of restructuring the economy and efficient privatization, politicians might obtain private benefits from hindering privatization'.

\section{Conventional versus emerging vested interests}

Traditional sources of vested interests include the temptation to forego economic rationality in exchange for "empire building" behaviors. Most of these issues can be viewed as classical principal-agent problems (Vickers and Yarrow, 1989). In the context of a non-privatized company, this boils down to three particular situations:

- "pumping up" the size of the company, e.g. through unnecessary investments or foreign expansion, which lacks economic rationale;

- the exploitation of sinecures, used to bolster one's political influence;

- unnecessary, non-austere perks for the management, such as luxurious limousines, leather armchairs, but also the new headquarters. For instance, one of the official Chinese reports, quoted by Cheng (2012:359) indicates that 'in a lot of loss-making SOEs, where workers could not receive wages, managers paid themselves full wages, bonuses, and subsidies, and rode around in luxury cars'.

The vested interests that may be deemed new to this universe are the following:

- creating additional channels of political influence and expanding the catalogue of incentives, with which politicians may please their networks (e.g. tolerating extravagant activity in the area of corporate social responsibility, sports sponsorship arrangements, lavish marketing expenses);

- proactive family employment (nepotism), of substantial value in the age of turbulent market environments.

Shleifer and Vishny (1994:1024) argue that the privatization is most likely to occur when politicians cannot obtain large benefits from public firms any more. This is an apparently obvious axiom, but what the literature frequently omits is that political benefits, as shown above, may alter. For instance, once public opinion stops to accept politicians deriving a particular benefit from public firms, politicians might "invent" a new, less controversial genre of benefits.

As it seems, the new vested interests display two traits. First, they are less unequivocal in terms of moral assessment, which means they are not unambiguously wrongdoings, at least at first glance. Such an inference is justified on the basis of a recent Public Opinion Research Center report (Centrum BadaniaOpiniiSpołecznej, 2012), where nepotism was not unequivocally despised. Second, they generally account for a more proactive role of the managers put in charge of the SOEs. In this view, the manager's (endowed's) vision is not solely the derivative of the politician's (endower's) vision. It is more independent and individualistic. 
It is generally difficult to decide whether these two are more exogenous or endogenous vested interests. On the one hand, they are derivatives of the independence of SOEs' management and as such, individuals in charge of SOEs are the main beneficiaries, enjoying prestige and respect. On the other hand, however, given complicated mutual relations and reciprocation schemes between politicians and their nominees, politicians do also have incentives to maintain a pool of attractive job posts to fill. And these two additional benefits undoubtedly add up to the attractiveness of managerial positions in SOEs.

\section{Illustrations of the problem}

One of the most prevalent bonuses associated with not privatized enterprises is the relatively convenient opportunity to spend money for non-business activity, including sports team ownership or sports sponsorship schemes. By participating in these, politicians associate themselves with positive emotions, playing the role of the "sugar daddy". In the communist era, economic flows activated not only by regular and fullfledged SOEs but also by state-owned farms on the more local level, aimed at supporting sport constituted an obvious necessity given no alternative source of financing (Andreff, 2008:23; Micek, Neo and Górecki, 2011:48). Contrary to the United States, where the so-called sports industry is resilient enough to secure vast resources, in much part of Europe the idea of subsidized sport outlived the totalitarian regimes. Nevertheless, public opinion is usually sensitive to the mismanagement of taxpayers' money by a beneficiary sporting entity (Andreff, 2006:9).

Table 2. A summary of SOE-related sports sponsorship activities for key professional leagues in Poland. Note: names of companies were put in parentheses only if they are not included in club's official name

\begin{tabular}{|c|c|c|c|}
\hline & & $\begin{array}{l}\text { Does SOE sponsors } \\
\text { the league? }\end{array}$ & Do SOEs sponsor particular clubs? \\
\hline Football & Men & No & $\begin{array}{l}\text { PGE GKS Bełchatów, RuchChorzów } \\
\text { (Węglokoks), while KGHM ZagłębieLubin is } \\
\text { fully owned by SOE }\end{array}$ \\
\hline \multirow[t]{2}{*}{ Basketball } & Men & $\begin{array}{l}\text { Yes (Tauron Basket } \\
\text { Liga) }\end{array}$ & $\begin{array}{l}\text { Energa Czarni Słupsk, PGE Turów } \\
\text { Zgorzelec, Polpharma Starogard Gdański } \\
\text { (Tauron), Stelmet Zielona Góra (PGNiG, } \\
\text { PKP Energetyka) }\end{array}$ \\
\hline & Women & No & EnergaToruń \\
\hline \multirow{2}{*}{ Volleyball } & Men & No & $\begin{array}{l}\text { PGE Skra Bełchatów, Jastrzębski Węgiel } \\
\text { (JSW), LOTOS Trefl Gdańsk }\end{array}$ \\
\hline & Women & Yes (ORLEN Liga) & $\begin{array}{l}\text { Atom Trefl Sopot (PGE), Tauron MKS } \\
\text { Dąbrowa Górnicza }\end{array}$ \\
\hline \multirow{2}{*}{ Handball } & Men & Yes (PGNiGSuperliga) & $\begin{array}{l}\text { OrlenWisłaPłock, AzotyPuławy, } \\
\text { TauronStalMielec }\end{array}$ \\
\hline & Women & Yes (PGNiGSuperliga) & $\begin{array}{l}\text { KGHM Metraco Zagłębie Lubin, SPR Lublin } \\
\text { (PGE) }\end{array}$ \\
\hline
\end{tabular}

It is not feasible to gather wide-ranging and accurate data on corporate involvement in sponsorship schemes. Even listed companies, although subject to rigorous discipline in terms of investor relations, do not have a duty to disclose such precise figures. This already should be a red flag for SOEs supervisors. Screening the yearly reports of twenty largest enterprises traded on the Warsaw Stock Exchange, reveals that whether firms share the details or not remains their discretionary choice. Nevertheless, Code of Best Practice for WSE Listed Companies (Warsaw Stock Exchange, 2011), updated 19 October 2011, says: 'If a company supports different forms or artistic and cultural expression, sport activities, educational or scientific activities, and considers its activity in this area to be a part of its business mission and development strategy, impacting the innovativeness and competitiveness of the enterprise, it is good practice to publish, in a mode adopted by the company, the rules of its activity in this area.' 
This rule should be applied not later than 1 January 2013. Based on yearly reports covering 2011, SOEs most often conceal their activity in this field. Such giants as Orlen, PGNiG or PGE, known for their active participation in sponsorship schemes, do not mention a word on it in their reports.

Table 3. A summary of 2011 management reports issued by the 20 largest companies on the Warsaw Stock Exchange (WIG20 is a capitalization-weighted stock market index)

\begin{tabular}{|c|c|c|c|c|c|}
\hline No. & Company & $\begin{array}{l}\text { Treasuryst } \\
\text { ake (direct) }\end{array}$ & $\begin{array}{l}\text { Free float } \\
\text { (mil PLN) }\end{array}$ & $\begin{array}{l}\text { WIG20 } \\
\text { share }\end{array}$ & $\begin{array}{c}\text { Nature of involvement in sports, } \\
\text { according to the } 2011 \text { official } \\
\text { yearly report }\end{array}$ \\
\hline 1 & KGHM & $31.79 \%$ & 26,395 & $15.086 \%$ & $\begin{array}{c}100 \% \text { ownership in } \\
\text { ZagłębieLubin S.A., } \\
\text { management of football section, } \\
\text { organization of professional } \\
\text { sporting events, enlisted as part } \\
\text { of CSR }\end{array}$ \\
\hline 2 & PKOBP & $33.39 \%$ & 24,036 & $13.738 \%$ & $\begin{array}{l}\text { Mentions several running events } \\
\text { that the bank supported }\end{array}$ \\
\hline 3 & PZU & $35.1875 \%$ & 23,674 & $13.531 \%$ & None \\
\hline 4 & PEKAO & - & 17,960 & $10.265 \%$ & None \\
\hline 5 & PKNORLEN & $27.52 \%$ & 15,903 & $9.089 \%$ & None \\
\hline 6 & PGE & $61.89 \%$ & 13,654 & $7.804 \%$ & None \\
\hline 7 & PGNIG & $73.50 \%$ & 8,596 & $4.913 \%$ & None \\
\hline 8 & TPSA & - & 8,092 & $4.625 \%$ & None \\
\hline 9 & TAURONPE & $30.06 \%$ & 5,145 & $2.940 \%$ & None \\
\hline 10 & BOGDANKA & 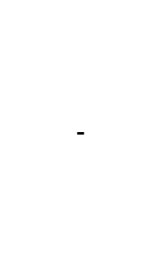 & 4,587 & $2.622 \%$ & $\begin{array}{l}\text { Admits that there is a separate } \\
\text { advertizing budget dedicated to } \\
\text { sports sponsorship }(7,932,500 \\
\text { PLN), along with the very broad } \\
\text { clarification of why the sports } \\
\text { sponsorship is important to the } \\
\text { firm. The report enumerates } \\
\text { clubs that have been supported. }\end{array}$ \\
\hline 11 & BRE & - & 4,162 & $2.378 \%$ & None \\
\hline 12 & JSW & $55.16 \%$ & 3,612 & $2.064 \%$ & None \\
\hline 13 & HANDLOWY & - & 3,247 & $1.856 \%$ & None \\
\hline 14 & KERNEL & - & 3,231 & $1.847 \%$ & None \\
\hline 15 & ASSECOPOL & - & 3,167 & $1.810 \%$ & $\begin{array}{c}\text { Mentions sponsorship } \\
\text { agreements with AssecoProkom } \\
\text { Gdynia (agreement set to expire } \\
\text { on } 31 \text { July 2015) and } \\
\text { AssecoResovia (until } 31 \text { May } \\
\text { 2014). }\end{array}$ \\
\hline 16 & SYNTHOS & - & 2,742 & $1.567 \%$ & None \\
\hline 17 & LOTOS & $53.18 \%$ & 2,468 & $1.411 \%$ & None \\
\hline 18 & GTC & - & 2,153 & $1.230 \%$ & None \\
\hline 19 & TVN & - & 1,568 & $0.896 \%$ & None \\
\hline 20 & BORYSZEW & - & 572 & $0.327 \%$ & None \\
\hline
\end{tabular}

Although sports sponsorship has been incorporated into the corporate marketing function over time (see Farrelly, Quester and Burton, 1997), there are doubts on whether the scope of support is not too lavish in the case of SOEs. There are also numerous examples of municipal firms, or municipalities directly, that sponsor professional sports. However, although controversial, this model does not lead to a geographical discrimination. Supporting the local team from local taxes may be considered as part of municipality's strategy to attract new inhabitants to the town or to provide them with entertainment. On the contrary, country-wide SOEs, if they invest locally, discriminate against other locations, which are deprived of their own sports team. Cherry-picking local teams to support at the cost of other regions seems to be a breach of neutrality. Since corporations back professional teams more enthusiastically than amateur sports and physical activity in general, the underlying moral case to be tackled is even more pronounced. 
Another problem associated with SOE-related vested interests is family employment. This not only concerns large nationwide corporations where such schemes are difficult to detect, but particularly the small-scale municipally-owned entities. Such a category usually comprises bus operators, waterworks companies, provision of public utilities, road maintenance or city cleaning services. In August 2012, "Rzeczpospolita" disclosed that 40 percent of Warsaw City Council members work for various governmental or self-governmental bodies. Overall, Polish mayors and heads of counties employ 250,000 people, whereas the central administration hires 180,000 . In the age of unemployment and bleak economic prospects, the ability to create jobs and hand-pick employees adds up much to the prestige of an official, who may derive rents and expect for reciprocation from those employed. It is not uncommon for the local governor to be a leading employer in a commune or in a county.

Sixteen voivodeship capitals operate 280 municipally-owned entities (including 44 in Warsaw only). Municipally-owned firms are attractive to territorial governments, since in many cases they allow for hiding debt. Since Poland's constitution caps debt to a pre-determined threshold, territorial governments have limited options for boosting their expenditures and thus municipally-owned entities become helpful in deceiving their true financial condition.In general, the privatization at the local level is a separate issue, with different set of incentives and disincentives. The level of complexity varies and while some scholars have found evidence that fiscal constraints, political and ideological considerations are decisive determinants of privatization policy (Bel and Fageda, 2009:116), others rather point out pragmatic concerns such as service quality (Warner and Hebdon, 2001).

A scandal that broke out in 2012 around the Agency for Restructuring and Modernisation of Agriculture (ARiMR) is edifying. As it became clear for the public, the agency, whose task is particularly to transfer the EU agriculture funds to Polish beneficiaries, has numerous staff. Apart from the headquarters with 25 departments and 16 regional offices, there are 314 local offices. It has over 10,000 employees in total and a considerable potential for sinecure creation. Simultaneosuly, the Agricultural Market Agency (ARR), with tasks partially overlapping with ARiMR, hires 1,200 people and - to make the picture full -there are additional 1,000 jobs in the already mentioned Agricultural Property Agency.

Some theoretical explanation of the phenomenon of nepotism in SOEs is offered by Santalainen, Baliga and Leimann (2003:78-79), who underline that the need to adjust to the free market standards inevitably leads to the disruption of prevailing corporate norms and values, part of which is providing employment to friends and relatives. They also highlight the excess employment that typically prevails in SOEs, and wrote about the problem of altered 'psychological contract' that invades safety of employees and gives rise to their disappointment. Gabris and Simo (1995) tried to discern whether the career motivations of public sector employees and private sector employees are contradictory, which would partially explain the perplexity of SOEs' employees when faced with privatization plans, but they did not arrive at any convincing results.

Having said that, we may conclude that SOEs have become full-grown extensions of the regular public authority. State-owned business units serve no more solely to protect the country's economic interest. The above mentioned case studies illustrate the multidimensional expansion of vested interests that indicates that they flourish rather than fall into decline.

Precisely, the corollary from screening these several cases is that the magnitude of the phenomenon is considerable and the innovation in inventing and exploiting the new sources of vested interests fell into a habit of the Polish government, territorial governments and SOEs. Whereas public opinion has already learnt how to blow the whistle to condemn the SOEs' behavior when conventional vested interests are manifested (which is not to say that these conventional sources are in decline), it still 
does not have tools, or will, to face the new wave of spoils. The delicateness of sports sponsorship, CSR or nepotism is evident. Criticizing the sponsorship of "glorious" goals may sometimes fail to attract many admirers. Criticizing nepotism must make anybody think twice, whether the claimant herself and her closest relatives are above suspicion. In the interconnected world of politics and bureaucracy, sinlessness is in deficit.

\section{Conclusions and policy implications}

This paper recognizes vested interests as one of the primary premises that reduce the effectiveness of privatization policy, stall its momentum and produce structural problems in the long-run. Since empire building behaviors, creation of sinecures or extravagant management style have all been identified by scholars long ago, this paper strove to unravel more up-to-date, emerging and yet unexploited sources of vested interests. The channels through which conventional vested interests have snowballed over time were briefly described. Among this new set of privatization constraints, a closer look was cast at employing relatives and engaging in lavish sports sponsorship arrangements. The latter appears to be the favorite domain of marketing activity for Polish SOEs.

Policy recommendations provided by the literature as regards the solution of the underlying deficiency read as follows. Alesina and Tabellini (2004:23) urge that if vested interests are in place, it is more efficient to let a non-elective bureaucrat handle a given problem than to have it retained by a politician, inherently vulnerable to voters' rage. A similar argument emerges from the inferences of Earle and Gehlbach (2002:5), as the absence of an established reform-oriented constituency is likely to produce a backlash when the inevitable privatization-related short-term costs occur. To mitigate the risk of premature policy reversal, some kind of "insulation" of the polity from the public may be considered. Moreover, Bortolotti and Pinotti (2003:9) seem to have found that the electoral system is important: the ones with majoritarian systems perform better and politicians are less likely to pursue rent seeking behaviors, as compared with the system based on proportional representation. Schindele (2003:13) puts forward a solution, too: bargaining models of privatization suggest that 'in order to achieve efficient privatization, corruption should be impossible and firms should face hard budget constraints', which necessitates the full coverage of costs with revenues. In fact, neither of these conditions has ever been met in full in Poland. The issue of implementation of any guidelines in the underlying matter remains difficult, due to the self-policing problem (nemoiudex in causa sua).

As far as the conclusions stemming directly from this paper are concerned, two policy recommendations seem justified. First, given no rapid privatization, the remuneration schemes in public enterprises call for amendment. The pattern of the compensation should be benchmarked to the market, reflecting the significance of the function, as well as ensure the appropriate level of motivation for the manager. The current "chimney bill", approved in 2000 under the populist pressure, is by no means the replication of the stimulating free market remuneration plans. Naturally, this will exert a tangible impact on the minimization of interest group influence only if it suffices to attract top-notch independent managers to SOE, and if it is accompanied by a fair and unbiased manager selection process. Second, the multilateral improvement in transparency should be demanded. This may capture both the overt and detailed information of all marketing arrangements that SOEs take up (what has been partly stipulated by the already mentioned Code of Best Practice for WSE Listed Companies), as well as the disclosure of all relevant conflicts of interest that decision makers might have. As soon as such conflicts arise, a politician or a bureaucrat should be advised to dissociate from the decision making, since the quoted examples from India or Japan proved that the detachment of reason and the subordination to pressure group interests are quite common when vested interests come into play. The antidote for the expanding set of vested interests lies obviously 
also in the ethical conduct of the ones in power, high standard of which being always deficient in transition economies. This, however, is the starting point for a completely different study.

There are several directions in which further investigation into the roots of vested interests should proceed. First, the paramount challenge is measurement. The quantitative tools are of limited value due to the poor data sets, data opacity and problematic sampling. Methods of how to navigate this paucity need to be improved. Second, the issue of universality seems interesting. Since this paper tries to display the Polish pattern of petrifying vested interests, it does not aspire to be considered ubiquitous. Third, the actual strength and durability of vested interests in the various stages of privatization processes is interesting. With regard to the last proposal, two hypotheses may be crafted to stimulate future research. One, vested interests have limited impact on the very beginning of transformation, when reformist enthusiasm is larger. Two, the nature of vested interests changes over time and new ones crowd out the older ones, what was partially argued in this paper.

\section{References}

Agarwal, Jamuna P. and Peter Nunnenkamp (1992) 'Methods and Sequencing of Privatization: What Post-socialist Countries Can Learn from Chile', Kiel Institute for the World Economy, Kiel Working Paper No. 527.

Alesina, Alberto F. and Guido E. Tabellini (2004) 'Bureaucrats or Politicians?', Center for Economic Studies \& Ifo Institute for Economic Research, Working Paper Series No. 1130.

Andreff, Wladimir (2006) 'New Perspectives in Sports Economics: A European View', AIES/IASE, Working Paper Series No. 06-05.

Andreff, Wladimir (2008) 'Globalization of the Sports Economy', Rivista di Diritto ed Economia dello Sport 4(3): 13-32.

Bauer, Johannes M. (2003) 'The Coexistence of Regulation, State Ownership and Competition in Infrastructure Industries: Quagmire or Institutional Innovation', Quello Center for Telecommunication Management and Law, Working Paper 003-2003.

Bel, Germà and Xavier Fageda (2008) 'Local Privatization, Intermunicipal Cooperation, Transaction Costs and Political Interests: Evidence from Spain', Research Institute of Applied Economics, Working Paper No. 2008/04.

Bel, Germà and Xavier Fageda (2009) 'Factors Explaining Local Privatization: A Meta-regression Analysis', Public Choice 139(1):05-119.

Bjørnskov, Christian and Niklas Potrafke (2011) 'Politics and Privatization in Central and Eastern Europe: A Panel Data Analysis', Economics of Transition 19(2): 201230.

Bortolotti, Bernardo and Mara Faccio (2004) 'Reluctant Privatization', Fondazione Eni Enrico Mattei, Working Paper No. 2004.130.

Bortolotti, Bernardo and Paolo Pinotti (2003) 'The Political Economy of Privatization', Fondazione Eni Enrico Mattei, Working Paper No. 2003.45.

Bortolotti, Bernardo and Paolo Pinotti (2008) 'Delayed Privatization', Bank of Italy, Working Paper No. 663.

Boycko, Maxim, Andrei Shleifer and Robert B. Vishny (1996) 'A Theory of Privatization', Economic Journal 106(435):09-319.

Campos, Nauro F. and Fabrizio Coricelli (2002) 'Growth in Transition: What We Know, What We Don't, and What We Should', William Davidson Institute, Working Paper No. 470. 
Careja, Romana and Patrick Emmenegger (2009) 'The Politics of Public Spending in Post-communist Countries', East European Politics and Societies 23(2):165-184.

Castater, Nichole M. (2002) 'Privatization as a Means to Societal Transformation: An Empirical Study of Privatization in Central and Eastern Europe and the Former Soviet Union', Fondazione Eni Enrico Mattei, Working Paper 2002.76.

Central Statistical Office in Poland [GłównyUrządStatystyczny] (2009) 'Prywatyzacjaprzedsiębiorstwpaństwowych w 2008 r.' [Privatization of state-owned enterprises in 2008], Warsaw.

Centrum BadaniaOpiniiSpołecznej [Public Opinion Research Center]. (2012) 'Polacy o nepotyzmie w życiupublicznym' [Opinions About Nepotism in Public Life], Research report no. BS/124/2012.

Checchi, Daniele, Massimo Florio and Jorge Carrera (2006) ‘Privatization Discontent and its Determinants: Evidence from Latin America', IZA Discussion Paper No. 1587.

Cheng, Xiaonong (2012) 'The Self-empowered New Master at the Workplace: Privatization in Russia and China', Department of Sociology at Princeton University, November, mimeo.

Christiansen, Hans (2011) 'The Size and Composition of the SOE Sector in OECD Countries', OECD Corporate Governance, Working Paper No. 5.

Christiansen, Hans (2013) 'Balancing Commercial and Non-commercial Priorities of State-owned Enterrises', OECD Corporate Governance, Working Paper No. 6.

Denisova, Irina, Markus Eller, Timothy Fryeand and Ekaterina Zhuravskaya (2010) 'Everyone Hates Privatization, but why? Survey Evidence from 28 Post-communist Countries', Centre for Economic and Financial Research at New Economic School, Working Paper No. 143.

Dinç, Serdar and Nandini Gupta (2011) 'The Decision to Privatize: Finance and Politics', Journal of Finance 66(1):241-269.

Earle, John S. and Scott Gehlbach (2002) 'A Spoonful of Sugar: Privatization and Popular Support for Reform in the Czech Republic', Upjohn Institute Staff, Working Paper No. 02-79.

Estrin, Saul, Jan Hanousek, Evzen Kocenda and Jan Svejnar (2007) 'Effects of Privatization and Ownership in Transition Economies', IPC Working Paper Series No. 30.

Faccio, Mara (2010) 'Differences Between Politically Connected and Nonconnected firms: A cross-country Analysis', Financial Management 39(3):905-928.

Farrelly, Francis J., Pascale G. Quester and Richard Burton (1997) 'Integrating Sports Sponsorship into the Corporate Marketing Function: An International Comparative Study', International Marketing Review 14(3):170-182.

Fischer, Stanley and Ratna Sahay (2000) 'The Transition Economies After Ten Years', National Bureau of Economic Research, Working Paper 7664.

Gabris, Gerald T. and Gloria Simo (1995) 'Public Sector Motivation as Independent Variable Affecting Career Decisions', Public Personnel Management 24(1): 33-51.

Galal, Ahmed, Leory Jones, Pankaj Tandon and Ingo Vogelsang (1994) Welfare Consequences of Selling Public Enterprises. Washington, DC: World Bank.

Godoy, Sergio and Joseph E. Stiglitz (2006) 'Growth, Initial Conditions, Law and Speed of Privatization in Transition Countries: 11 Years Later', National Bureau of Economic Research Working Paper 11992.

Goldstein, Andrea and Giuseppe Nicoletti (2003) 'Privatization in Italy 1993-2002:

Goals, Institutions, Outcomes, and Outstanding Issues', Prepared for the CESifo 
conference on privatization experiences in the EU, held in Munich on 10/11 January 2003.

Gupta, Nandini, John C. Ham and Jan Svejnar (2008) 'Priorities and Sequencing in Privatization: Evidence from Czech Firm Panel Data', European Economic Review 52(2):183-208.

Gwiazda, Anna (2008) 'Party Patronage in Poland: The Democratic Left Alliance and Law and Justice Compared', East European Politics and Societies 22(4): 802-827.

Hertog, Steffen (2010) 'Defying the Resource Curse: Explaining the Successful State-owned Enterprises in Rentier States', World Politics 62(2): 261-301.

Hillman, Amy J. (2005) 'Politicians on the Board of Directors: Do Connections Affect the Bottom Line?', Journal of Management 31(3): 464-481.

limi, Atsushi (2002) 'An Empirical Note: Privatization Transaction and Macroeconomy in Developing Countries', JBICI Working Paper No. 10.

Imai, Masami (2009) 'Ideologies, Vested Interest Groups, and Postal Saving Privatization in Japan', Public Choice 138(1/2): 137-160.

Jamasb, Tooraj (2006) 'Between the State and Market: Electricity Sector Reform in Developing Countries', Utilities Policy 14(1): 14-30.

Kapstein, Ethan B. and Branko Milanovic (2000) 'Dividing the Spoils: Pensions, Privatization, and Reform in Russia's Transition', World Bank Policy Research Working Paper No. 2292.

Khwaja, Asimljaz and Atif Mian (2005) 'Do Lenders Favor Politically Connected Firms? Rent Provision in an Emerging Financial Market', The Quarterly Journal of Economics 120(4):1371-1411.

Kowalik, Tadeusz (1991) 'Marketization and Privatization: The Polish Case', in Miliband, Ralph, Panitch, Leo. (eds.) Communist Regimes: The Aftermath, London: Merlin, pp. 259-278.

Kozarzewski, Piotr (2008) 'Corporate Governance Formation in Poland, Kyrgyzstan, Russia and Ukraine', in McGee, Robert W. (eds.) Corporate Governance in Transition Economics, London: Springer, pp. 251-288.

Krusell, Per and José Victor Rios-Rull (1996) 'Vested Interests in a Positive Theory of Stagnation and Growth', The Review of Economic Studies 63(2):301-329.

Lewis, David E. (2009) 'Patronage Appointments in the Modern Presidency: Evidence from a Survey of Federal Executives', Vanderbilt Law and Economics Research Paper No. 09-24, Vanderbilt Public Law Research Paper No. 09-20.

Li, David D. and Francis T. Lui (2004) 'Why Do Governments Dump State Enterprises: Evidence from China', in Takatoshi Ito and Anne O. Krueger (eds) Governance, regulation, and privatization in the Asia-Pacific region, NBER East Asia Seminar on Economics 12:211-230.

Lipton, David and Jeffrey Sachs (1990) 'Privatization in Eastern Europe: The Case of Poland', Brookings Papers on Economic Activity 2: 293-341.

Majcherkiewicz, Tatiana, Gadowska, Kaja (2005) 'Political Clientelism in Public Administration: A Case Study of Institutional Changes in the Post-communist State of Poland', Paper presented at the $13^{\text {th }}$ NISPAcee Annual Conference: 'Democratic Governance for the XXI Century: Challenges and Responses in CEE Countries', 1921 May 2005, Moscow.

Megginson, William L., Bortolotti, Bernardo (2011) 'Privatization Trends and Major Deals in 2010 and 1 H2011',URL (consulted May 2014): http://ssrn.com/abstract=2136780. 
Megginson, William L., Robert C. Nash and Matthias van Randenborgh (1994) 'The Financial and Operating Performance of Newly Privatized Firms: An International Empirical Analysis', The Journal of Finance 49(2):403-452.

Megginson, William L. and Jeffry M. Netter (1998) 'From State to Market: A Survey of Empirical Studies on Privatization', NYSE Working Paper 98-05.

Micek, Grzegorz, Harvey Neo and Janusz Górecki (2011) 'Foreign Direct Investment, Institutional Context and the Changing Polish Pig Industry', GeografiskaAnnaler: Series B, Human Geography 93(1):41-55.

Ministry of Treasury in Poland (2005) 'Raport o przekształceniachwłasnościowych w 2004 roku' [Report on ownership transformation in 2004], Warsaw: Author.

Money.pl (2008) 'Polskaustawakominowajedyna w krajach UE' [Polish "chimney bill" is the only one in the EU], URL (consulted March 2014): http://prawo.money.pl/ aktualnosci/wiadomosci/artykul/polska;ustawa;kominowa;jedyna;w;krajach;ue,120, 0,330360.html.

Moors, Kent F. (1997) 'The Failure of Russian Privatization 1992-1994: How the Industrial Nomenklatura Prevented Genuine Reform', Journal of International Legal Studies 3(1):1-52

Newton, Ashley N., Uysal, Vahap B. (2013) The Impact of Political Connectedness on Firm Value and Corporate Policies: Evidence from Citizens United. Mimeo: University of Oklahoma.

Nowakowski, Krzysztof (2005) 'Problems of Clientelism and Corruption in Poland', Review of Sociology 11(2): 75-86.

Olofsgård, Anders (2003) 'The Political Economy of Reform: Institutional Change as a Tool for Political Credibility', Background paper to the World Bank's 2005 World Development Report.

Open Society Institute. (2002) 'Corruption and Anti-corruption Policy in Poland', in Monitoring the EU accession process: Corruption and anti-corruption policy, New York: Author, pp. 393-450.

Opper, Sonja (2004) 'The Political Economy of Privatization: Empirical Evidence from Transition Economies', Kyklos 57(4):559-586.

Radwan, Arkadiusz and Tomasz Regucki (2012) 'The Possibilities For and Barriers to Sustainable Companies in Polish Company Law', University of Oslo Faculty of Law Research Paper No. 2012-32.

Raszewski, Sławomir (2012) 'Security and the Economics of Energy in North East Europe', in Kuzemko, Caroline, Belyi, Andrei, Goldthau, Andreas, Keating, Michael F. (eds) Dynamics of energy governance in Europe and Russia, London: Palgrave Macmillan, pp. 130-148.

Rattsø, Jørn, Sørensen, Rune J. (2012) 'Political Control of Government Enterprises: Who Controls Whom?', Norwegian University of Science and Technology and Norwegian Business School.

Roland, Gérard (2000) Transition and Economics. London and Cambridge: MIT Press.

Roland, Gérard (2001) 'Corporate Governance Systems and Restructuring: The Lessons from the Transition Experience', in Annual Bank Conference on Development Economics 2000. Washington: World Bank, pp. 331-352.

Rondinelli, Dennis A. and Jay B. Yurkiewicz (1996) 'Privatization and Economic Restructuring in Poland: An Assessment of Transition Policies', American Journal of Economics and Sociology 55(2):145-160. 
Rosa, Jean-Jacques and Edouard Pérard (2010) 'When to Privatize? When to Nationalize? A Competition for Ownership Approach', Kyklos 63(1):110-132.

RynekInfrastruktury.pl (2012) 'Rząd pracuje nad zmianami w ustawie kominowej.Ekspercichcajejlikwidacji' [The government plans to update the "chimney bill". Experts demand their abolition], 19 July, URL (consulted March 2014): http://www.rynekinfrastruktury.pl/artykul/112/1/rzad-pracuje-nad-zmianami-wustawie-kominowej-eksperci-chca-jej-likwidacji.html.

Santalainen, Timo J., Ram B. Baliga and Jaak Leimann (2003) 'Straddling for Market Space: Transforming Estonian State-owned Enterprises Toward a Free-market Orientation', International Business \& Economics Research Journal 2(9):75-87.

Schindele, Ibolya (2003) 'Theory of Privatization in Eastern Europe: Literature Review', Fondazione Eni Enrico Mattei, Working Paper No. 2003.2.

Schoenman, Roger (2005) 'Captains or Pirates? State-business Relations in Postsocialist Poland', East European Politics and Societies 19(1): 40-75.

Shafik, Nemat (1996) 'Selling Privatization Politically', International Journal of the Economics of Business 3(3): 367-378.

Shleifer, Andrei and Robert W. Vishny (1994) 'Politicians and Firms', Quarterly Journal of Economics 109(4): 995-1025.

Šikulová, Ivana and Karol Frank (2013) 'The Slovak Experience with Transition to Market Economy', Ekonomický ústav SAV Working Paper No. 49.

Singh, Nirvikar (2010) 'The Dynamics and Status of India's Economic Reforms', MPRA Paper No. 24479.

Stark, David (1990) 'Privatization in Hungary: From Plan to Market or from Plan to Clan', East European Politics and Societies 4(3): 351-392.

Stiglitz, Joseph (2002) Globalization and its Discontents. London: Penguin Books.

Tache, lleana (2008) The Mass Privatization Process in Romania: A Case of Failed Anglo-Saxon Capitalism. Mimeo: Transilvania University of Brasov.

Tirole, Jean (1991) 'Privatization in Eastern Europe: Incentives and the Economics of Transition', in Blanchard, Olivier J., Fisher, Stanley. (eds) NBER Macroeconomics Annual 1991, 6, Cambridge: MIT Press.

Van de Walle, Nicolas (1989) 'Privatization in Developing Countries: A Review of the Issues', World Development 17(5):601-615.

Vickers, John and George Yarrow (1989) Privatisation: An Economic Analysis. London: MIT Press.

Vitkus, Gediminas (2009) 'Russian Pipeline Diplomacy: A Lithuanian Response', Acta Slavica laponica 26:25-46.

Wallsten, Scott J. (2002) 'Does Sequencing Matter? Regulation and Privatization in Telecommunications Reforms', Development Research Group, World Bank.

Warner, Mildredand and Robert Hebdon (2001) 'Local Government Restructuring: Privatization and its Alternatives', Journal of Policy Analysis and Management 20(2): 315-336.

Warsaw Stock Exchange (2011) 'Code of best practice for WSE listed companies:Appendix to Resolution No. 20/1287/2011 of the Exchange Supervisory Board', 19 October 2011, URL (consulted May 2014): http://www.corpgov.gpw.pl/assets/library/english/ regulacje/bestpractices\%2019_10_2011_en.pdf.

Watts, Michael, Willian B. Walstad and Alexander Skiba (2002) 'Attitudes Toward Markets and Market Reforms in the Former Soviet Union and Eastern Europe', in 
Watts, Michael and Willian B. Walstad (eds.) Reforming economics and economics teaching in the transition economies: From Marx to markets in the classroom, Cheltenham and Northampton, MA: Edward Elgar Publishing, pp. 8-34.

Wu, Jianfeng and Menita Liu Cheng (2011) 'The Impact of Managerial Political Connections and Quality on Government Subsidies: Evidence from Chinese Listed firms', Chinese Management Studies 5(2): 207-226.

Yusuf, Shahid (2009) Development Economics Through the Decades: A Critical Look at Thirty Years of the World Development Report. Washington, DC: World Bank.

Zinnes, Clifford, Yiar Eilat and Jeffrey Sachs (2001) 'The Gains from Privatization in Transition Economies: Is "Change of Ownership" Enough?', IMF Staff Papers 48(Special Issue):146-170. 